\title{
Membingkai Kepribadian Anak dengan Pola Asuh pada Masa Covid 19
}

\author{
Hadi Machmud \\ Pendidikan Islam Anak Usia Dini, IAIN Kendari \\ e-mail : machmud657@gmail.com
}

\begin{abstract}
ABSTRAK. Artikel ini bertujuan untuk mengetahui pola asuh orang tua dalam membingkai kepribadian anak usia 4-6 tahun dimasa pandemi covid 19. Metode yang digunakan kualitatif studi kasus melalui pengamatan, wawancara dan dokumentasi pada 11 orang (4 Ayah dan 7 Ibu) di Kelurahan Baruga kota Kendari. Data dianalisis dengan menggunakan tematik, menekankan pada penyusunan koding dengan mengacu pada pertanyaan penelitian yang telah ditetapkan sehingga tema-tema yang tersusun sesuai dengan pertanyaan penelitian sekaligus menjadi acuan dalam memaparkan fenomena yang terjadi. Hasil penelitian secara umum pola asuh yang diterapkan orang tua adalah autoritatif, authoritarian, permissive, neglectful/ uninvolved. Dengan penerapan pola asuh tersebut anak tumbuh kembang secara kreatif, baik patuh, mempunyai tanggung jawab, percaya diri, dapat menerima pahit manisnya kehidupan ketika dewasa, berpikiran positif, kreatif dan aktif, beradab, prilaku sopan, empati dan mencintai sesama makhluk.
\end{abstract}

Kata Kunci : Kepribadian, Anak usia 4-6, Pola Asuh, Covid 19.

ABSTRACT. This article aims to determine parenting styles in framing the personalities of children aged 4-6 years during the COVID-19 pandemic. The method used is qualitative case studies through observation, interviews and documentation on 11 people (4 fathers and 7 mothers) in Baruga district of Kendari. Data were analyzed using thematic, emphasizing the preparation of coding with reference to the research questions determined so that the themes were arranged according to the research question as well as a reference in describing the phenomena. The results of the study, in general, the parenting styles applied by parents are authoritative, authoritarian, permissive, negative / uninvolved. By impleementing these parenting styles, children grow and develop their creativity, obey, have responsibility, are confident, can accept reaality of life as an adult, think positively, are creative and active, civilized, behave politely, have empathy and love their fellow beings.

Keyword : Personality, Children aged 4-6, Parenting, Covid 19. 


\section{PENDAHULUAN}

“Covid 19" sebuah nama yang menakutkan dan menyeramkan penduduk dunia dewasa ini, dia merupakan bencana non alam yang tidak berwujud, keberadaannya telah merenggut jutaan nyawa manusia dan telah menimbulkan ketakutan, keresahan dan masalah disemua sektor. Menurut WHO Coronaviruses (CoV) merupakan bagian dari keluarga virus yang menyebabkan penyakit mulai dari flu hingga penyakit yang lebih berat seperti Middle East Respiratory Syndrome (MERS-CoV) and Severe Acute Respiratory Syndrome (SARS-CoV). Penyakit yang disebabkan virus corona, atau dikenal dengan COVID-19, adalah jenis baru yang ditemukan pada tahun 2019 dan belum pernah diidentifikasi menyerang manusia sebelumnya [1]. Data terakhir dari Komite Penanggulangan Covid 19 tanggal 25 Agustus 2020 menyebutkan bahwa virus ini telah menginfeksi 5,623,503 orang, dengan jumlah kematian 348,760 jiwa dan jumlah pasien yang sembuh $2,393,551$ pada 213 negara [2]. Sementara di Indonesia pada saat tulisan ini disusun telah terkonfirmasi ada 157.859 yang positif, sembuh 112.867 , dan 6.858 yang meninggal. Saat ini telah menginfeksi 23,165 orang dengan jumlah kematian 1,418 jiwa, dan jumlah pasien yang sembuh 5,877 orang [3]. Pemerintah telah melakukan berbagai upaya untuk memutus mata rantai penyebaran virus ini, di antaranya dengan mengeluarkan PP Nomor 21 tahun 2020 tentang Pembatasan Sosial Berskala Besar dalam rangka percepatan penanganan Covid-19 yang berdampak pada pembatasan berbagai aktivitas masyarakat.

Selain itu, Kementerian PPPA sudah memiliki jaringan Forum Anak yang tersebar di 34 provinsi, 451 kabupaten/kota dan ribuan kecamatan dan desa menjelaskan "Kalau kita lihat anak-anak kreatif, inovatif mensosialisasikan 3M (memakai masker, menjaga jarak dan menjauhi kerumunan). Diharapkan langkah-langkah efektif dan massif yang bisa kita lakukan dapat mengurangi klaster keluarga ini," ungkapnya[4]. Selanjutnya disampaikan pada masyarakat luas jika ada anggota keluarganya tertular, langsung hubungi puskesmas terdekat atau dinas kesehatan (Dinkes) setempat. Nantinya dinkes melaporkan kepada Satgas Covid-19 di daerahnya masing-masing, untuk biayanya akan ditanggung pemerintah [5].

Keberadaan pandemi covid 19 dibelahan dunia telah mempengaruhi kehidupan setiap individu seperti pandangan hidup, pola hidup, pola makan, kebiasaan, kesehatan, kebersamaan, menghargai dan yang terutama menghargai kehidupan berkeluarga. Semua dipaksa untuk dapat beradaptasi dengan perubahan yang terjadi akibatnya banyak yang mengalami stress, tekanan, dan bahkan memunculkan masalah baru. Sebahagian orang tua dalam keluarga ada yang merasa stress, depresi dan tekanan karena harus menyeimbangkan antara pekerjaan, merawat anak, dan pekerjaan rumah, terutama pada saat mereka terpisah dengan jejaring pendukung yang biasa dimiliki. Sejatinya isolasi bisa membawa kesempatan untuk menghabiskan waktu bersama dan mengembangkan hubungan orang tua dengan anggota keluarga terutama anak-anak [6]. Realitas yang ada sebahagian orangtua mengalami konflik perasaan, prioritas, tantangan praksis lainny. mempengaruhi prilaku dan polah hidup semua strata sosial keluarga dan telah menimbulkan berbagai dampak negatif (stress) dalam keluarga sekaligus dampak positif seperti keakraban, kehangatan serta perhatian dalam keluarga. Orang tua memiliki waktu dan kesempatan lebih banyak memperhatikan, membimbing, mendidik 
dan mendampingi anak dalam melakukan aktivitas sekaligus membentuk kepribadian mereka.

Sjarkawi menjelaskan bahwa Kepribadian yang dimiliki seseorang akan berpengaruh terhadap akhlak, moral, budi pekerti, etika, dan estetika orang tersebut ketika berinteraksi dan berkomunikasi dengan orang lain dalam kehidupan sehari-hari di manapun dia berada". Dalam keluarga, peranan orang-tua maupun saudara berpengaruh dalam membentuk kepribadian anak. Pola asuh dari orang-tua yang baik akan melahirkan perilaku yang baik pula bagi anak. Selanjutnya dikatakan bahwa ada lima penggolongan tipe kepribadian yaitu tipe sanguinis, phlegmatis, melankolis, kholeris dan asertif. Pada tipe sanguinis menggambarkan seseorangyang memiliki tipe kepribadian bersemangat dalam bekerja, mampu membuat lingkungan menjadi senang dan gembira[7]. Kemudian tipe phlegmatis menggambarkan individu yang pembawaannya tenang, gejolak emosinya tidak tampak, mudah mengintropeksi diri. Sedangkan pada tipe melankolis merupakan orang yang cendrung terobsesi dengan karyanya sendiri, perasaannya sangat kuat dan sangat sensitif. Selanjutnya tipe kholeris digambarkan dengan seseorang yang disiplin dalam bekerja, dan bertanggung jawab atas tugas yang diberikan. Terakhir, tipe asertif, yaitu seseorang yang mampu menyatakan pendapat, mau mengemukakan gagasan secara tegas, kritis, dan dalam berbicara mencerminkan perasaannya yang halus.

Umar Hasyim menjelaskan dalam bukunya yang berjudul, "Anak Soleh (Cara Mendidik Anak dalam Islam)”, mengutip dari yang diungkapkan Kartini Kartono, bahwa Keluarga merupakan lembaga pertama dalam kehidupan anak, tempat ia belajar dan menyatakan diri sebagai makhluk sosial [8]. QS. Al-Tahrim ayat 6 menjelaskan bahwa dalam keluarga umumnya anak ada dalam hubungan interaksi yang intim. Keluarga memberikan dasar pembentukan tingkah laku, watak, moral, dan pendidikan anak, mengerjakan apa yang diperintahkan" [9]. Rumah dan keluarga menjadi pilar utama dalam pembentukan kepribadian anak maka pengasuhan anak, siapapun menjadi sosok yang paling dominan dalam mempengaruhi kepribadian anak. Karena itu sangat penting bagi orang tua menjadi pengasuh utama bagi darah dagingnya, karena ia akan menyayangi dan mendidik dengan sepenuh hati. Sebagaimana dijelaskan dalam Hadits di bawah ini : "Dari Abu Hurairah Radiyallahu anhu, Rasulullah SAW bersabda : Setiap anak itu dilahirkan dalam keadaan fitrah kedua orang tuanyalah yang membuat menjadi seorang Yahudi, seorang Nasrani maupun Majusi." (HR. Abu Hurairah Radhiyallahu'anhu). Menurut Desmita salah satu aspek penting dalam hubungan orangtua dan anak adalah gaya pola asuh orang tua yang dilakukan kepada anak, dengan demikian, pola asuh orang-tua dalam mendidik anak pada keluarga sangat penting, di keluargalah seorang anak mula-mula memperoleh bimbingan dan pendidikan dari orang-tua, oleh karena itu penanaman bimbingan orang-tua harus ditekankan sesuai dengan pola asuh [8].

Dalam Kamus Bahasa Indonesia pola asuh atau pengasuhan merupakan cara perbuatan untuk menjaga, merawat, mendidik, membimbing, anak-anaknya agar berkembang sesuai tahapannya [10]. Pengasuhan orang tua diharapkan dalam memberikan kedisiplinan terhadap anak, memberikan tanggapan yang sebenarnya agar 
anak merasa orang tua selalu memberikan perhatian yang positif terhadapnya. Baumrind (dalam Silalahi), mengatakan bahwa gaya pola asuh orang-tua ada empat tipe yaitu otoriter, demokratis, permisif, uninvolved. Dijelaskan pada pola asuh otoriter, ditandai dengan adanya aturan-aturan yang kaku dari orang-tua, cenderung untuk menentukan peraturantanpa berdiskusi dengan anak-anak mereka terlebih dahulu. Pada pola asuh demokratis, orang tua lebih mendorong kemandirian pada batasan tertentu, hangat dan penuh kasih sayang sehingga anak mampu berkompeten secara sosial, mampu bergantung pada diri sendiri bertanggung jawab secara sosial. Selanjutnya pada pola asuh permisif yang sedikit terlibat dengan anak dan tidak menyadari apa yang dilakukan anak. Terakhir pola asuh orang tua uninvolved merupakan pola asuh yang paling buruk dari ketiga pola asuh yang telah dijelaskan di atas, karena orang-tua tidak memiliki kontrol terhadap anak sama sekali, orang tua membiarkan apa saja yang dilakukan oleh anak [11].

Abu Ahmadi menjelaskan dalam bukunya yang berjudul "ilmu pendidikan", mengutip dari Imam Ghazali yang mengatakan : Anak itu sifatnya menerima semua yang dilakukan, yang dilukiskan dan condong kepada semua yang tertuju kepadanya. Jika anak dibiasakan diajari berbuat baik maka anak itu akan hidup berbahagia di dunia dan akhirat [12]. Dari kedua orang tua serta semua guru-gurunya dan pendidik-pendidiknya akan mendapat kebahagiaan pula dari kebahagiaan itu. Tetapi jika dibiasakan berbuat jahat dan dibiarkan begitu saja, maka anak itu akan mencela dan binasa. Maka yang menjadi ukuran dari ketinggian anak itu ialah terletak pada siapa yang bertanggung jawab (pendidik) dan walinya. Tidak dapat dipungkiri bahwa masa pandemi covid 19 telah membawa dampak dan perubahan yang berbeda pada setiap orang terutama kehidupan keluarga, aktivitas lebih banyak dilakukan dari rumah, dan tidak sedikit kegiatan yang harus terhenti. Menurut Aris bahwa nilai pendidikan Islam yang ditrasformasikan pada anak adalah nilai aqidah berupa mengucapkan kalimat-kalimat istighfar dan membiasakan melafalkan syahadat. Selanjutnya nilai amaliyah yaitu membiasakan membaca doa-doa harian dan membiasakan pola hidup bersih dan sehat dengan mencuci tangan dan memakai masker[13]. Menurut Tanjung bahwa peran orang tuadalam pendidikan anak usia dini dapat disimpulkan orang tua mengkondisikan lingkungan keluarga dengan menjadikan rumah sebagai tempat yang nyman untuk menunjang pendidikan anak. Ayat- ayat Al-Qur'an selalu diperdengarkan setiap malam dirumah[14].

Kondisi ini tidak mudah bagia setiap orang yang terbiasa mempunyai aktivitas lebih banyak di luar rumah. Unicef menyampaikan beberapa kiat-kiat praktis orang tua dalam pengasuhan sekaligus membentuk karakter anak dimasa pandemi ini, yaitu; pertama waktu berkualitas dengan masing-masing anak dengan banyak membuat kegiatan istimewa bersama dengan anak untuk membangkitkan cinta, kasih sayang, rasa aman, pengakuan anak akan pentingnya dirinya, kedua selalu memberikan pujian, perintah yang positif misalnya memenita anak melakukan sesuatu dengan berkata "tolong simpan bajumu, ya' bukan dengan kata "jangan bikin berantakan", ketiga mengatur nada suara, tidak membentak karena hanya membuat anak stres dan marah baik pada orang lain maupun dengan dirinya sendir, keempat memberikan pujian atas 
apa dilakukan dan prilakunya, dengan begitu anak akan merasa senang dan akan melakukan lagi hal yang menyenangkan, kelima tetap realistis, orang tidak boleh melakukan sesuatu yang dilarang untuk dilakukan anak, sementara orang tuanya dapat melakukan, misalnya anak dilarang main HP (gedget) tetapi orang tua asik menelpon dan main game, bermain medsos, keenam membuat jadwal yang realistis, fleksibel, dan tetap kosisten misalnya melakukan sesuatu dimulai dari orang tua dengan contoh meminta anak untuk melakukan, ketujuh mengatasi prilaku yang kurang baik misalnya apabila melihat anak mulai gelisah maka alihkan perhatiannya dengan menawarkan kegiatan menarik dan menyenangkan seperti berjalan-jalan disekitar rumah, kedelapan ajarkan anak bertanggung jawab atas tindakannya, berdisiplin, berikan kesempatan melakukan hal-hal yang disukai dan berikan pujian jika dia berhasil, kesembilan tetap tenang dan sabar, hindari media sosial yang membuat panik, berikan waktu beristirahat yang cukup, selalu terbuka dan mendengarkan keluhan, simak cerita mereka, curahan hati, berikan ketenangan dan perasaan nyaman, kesepuluh menceritakan tentang covid 19, apa yang dimaksud dengan virus corona, dampaknya, bagaiaman menyebarannya, apa yang harus dilakukan agar tidak tertular, bagaiman kondisi orang yang terinfeksi corona, bagaiman cara penyembuhannya, dan lain sebagainya, jelaskan kondisi masyarakat sekarang akibat pandemi corona [15].

Pelaksanakan pra observasi yang dilakukan pada beberapa keluarga di Kelurahan Baruga Kota Kendari ditemukan bahwa pada masa pandemi covid 19 terjadi perubahan pada seluruh aktivitas kehidupan masyarakat dan keluarga. Seluruh aktivitas dilakukan dari rumah termasuk bekerja dan belajar, maka pada saat yang bersamaan berlaku pola hidup yang baru termasuk pola asuh orang tua dalam mendidik, membimbing, dan mengembangkan potensi anak terkhusus membingkai kepribadian anak. Wawancara dengan beberapa orang tua diperoleh data awal bahwa pola asuh yang diterapkan orang tua sesuai dengan budaya dan kebiasaan dengan menanamkan nilai-nilai yang diyakini baik dan benar bagi anak terutama dalam membentuk kepribadian mereka. Pola asuh yang diterapkan orang tua dalam membentuk kepribadian selama masa pandemi covid 19 ada bermacam-macam, namun secara umum dapat rangkum dalam; pola asuh demokrasi, pola asuh otoriter, permisif, dan pola asuh tidak terlibat.

Berdasarkan uraian di atas maka penelitian ini bertujuan untuk mengetahui lebih jauh bagaimana pola asuh orang tua dalam mengasuh, membimbing dalam membingkai kepribadian anak dimasa pandemi covid 19. Penelitian memfokuskan pada "Bagaimana pola asuh yang diterapkkan orang tua dalam membingkai kepribadian anak dan upaya apa saja yang dilakukan orang tua untk membentuk kepribadian anak dimasa covid 19".

\section{METODE}

Penelitian ini menggunakan metode kulaitatif studi kasus untuk mengungkap secara rinci dan komprehensif mengenai situasi dari objek yang dianalisis [16]. Yin, menyatakan bahwa studi kasus sangat sesuai untuk menjawab pertanyaan "bagaimana" karena jenis pertanyaan seperti ini akan mengekplorasi data lebih dalam [17]. Penelitian ini akan menganalisis pola asuh orang tua dalam membentuk kepribadian anak dimasa 
pandemi Covid-19. Subjek dalam penelitian ini adalah orang tua yang memiliki anak usia dini dan usia berusia 4-6 tahun yang berjumlah 11 orang (4 Ayah dan 7 Ibu). Teknik pengumpulan data menggunakan observasi dan wawancara, dengan dukungan dokumentasi, data kemudian dianalisis dengan menggunakan tematik, yaitu teknik analisis yang menekankan pada penyusunan koding dengan mengacu pada pertanyaan penelitian yang telah ditetapkan, sehingga tema-tema yang tersusun sesuai dengan pertanyaan penelitian sekaligus menjadi acuan dalam memaparkan fenomena yang terjadi [18]. Secara lebih rinci paparan alur penelitian dapat dilihat pada gambar di bawah ini:

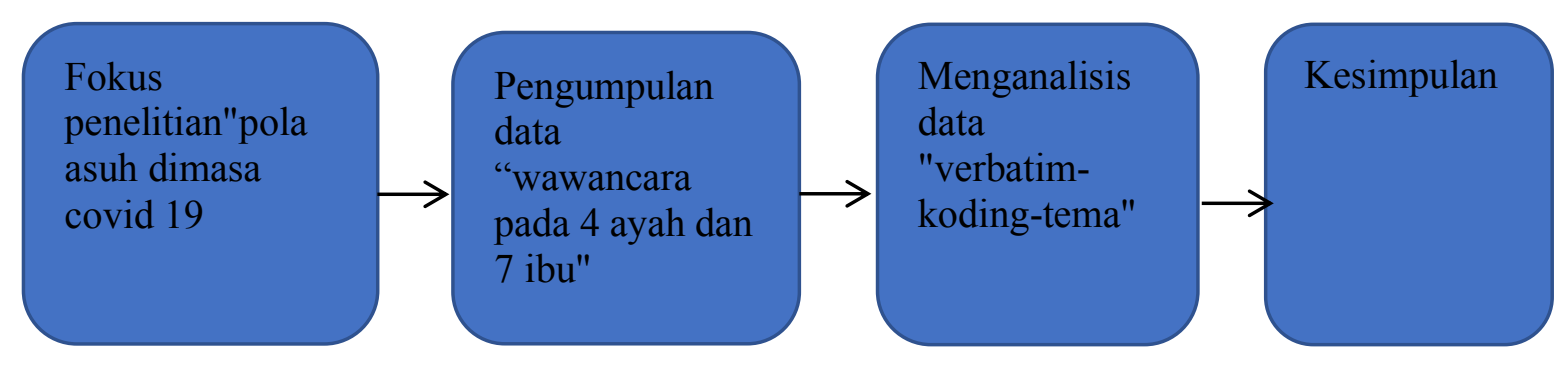

Gambar 1. Alur Penelitian

\section{HASIL DAN PEMBAHASAN}

Berdasarkan data yang diperoleh dengan teknik observasi dan wawancara pada 11 orang informan dari orang tua anak yang berusia 4-6 tahun sebagai terteliti, kemudian melakukan analisis ditemukan bahwa pola asuh yang diterapkan orang tua dalam membentuk membingkai kepribadian anak pada masa pandemi covid 19 di Kelurahan Baruga kota Kendari secara umum terungkap bahwa orangtua memiliki keinginan, harapan dan cita-cita terhadap anak-anak yaitu mereka menginginkan agar anak-anak mereka menjadi orang yang patuh, taat beribadah, berakhlak mulia, berbakti terhadap orangtua, suka menolong, pintar, cerdas, terampil, mudah bergaul, berperilaku baik, tegas, disiplin, sukse dan berhasil dimasa mendatang.

Keluarga sebagai wadah pendidikan utama dan pertama bagi anak memiliki peran yang amat besar dalam membentuk kepribadian anak seperti kemandirian, kebiasaan, adab, akhlak, sopan santun, kepercayaan pada diri sendiri, dan ketekunan, rajin dan patuh. Keluarga merupakan tempat pertama kali anak belajar menyatakan diri sebagai mahkluk sosial dalam berinteraksi dengan kelompoknya. Keluarga yang dinahkodai oleh orang tua bertanggung jawab dalam pengendalikan seluruh anggota keluarga. Setiap keluarga memiliki harapan-harapan atau keinginan-keinginan, cita-cita yang hendak dicapai di masa depan. Harapan dan keinginan orangtua terhadap anakanaknya di masa depan inilah yang akan banyak mempola asuhi bagaimana mereka memperlakukan anak-anaknya, memberi tugas dan tanggung jawab, serta pemenuhan terhadap kebutuhan anak-anaknya, baik fisik dan psikis, termasuk, memberi perhatian, kasih sayang dan perlindungan terhadap buah hatinya. Dengan kata lain, orangtua akan menggunakan pola asuh tertentu untuk merealisasikan harapan dan keinginan. Pola asuh yang dimaksud dapat direfleksikan dalam bentuk perlakuan fisik maupun psikis seperti tercermin dari tutur kata, sikap, perilaku dan tindakan mereka. Ada yang cenderung kaku (otoriter), acuh tak acuh/serba membolehkan (permisif), ada yang demokratis bahkan ada yang yang tidak terlibat secara langsung. Hal ini diperkuat oleh Conny R. Semiawan bahwa anak manusia akan menempatkan diri dalam tumbuh 
kembang di mana ia berada melalui pengalaman positif dan pengalaman menyimpang. Berbagai pengalaman itu akan diabsorp (terhisap) dengan sendirinya. Namun untuk itu, ada kebutuhan yang diperlukan yaitu media keluarga [19].

Penerapan pola asuh yang berbeda-beda dari orang tua terhadap anak-anaknya dipengaruhi oleh beberapa faktor, antara lain; Faktor Sosial Ekonomi, Faktor Jumlah Anak, Faktor Kepribadian, Faktor Lingkungan dan Budaya, Faktor Pendidikan [20]. Selanjutnya teori D. Baumind menjadi empat macam pola asuh, yaitu; pertama pola asuh demokratis, kedua pola asuh otoriter, ketiga pola asuh permisif atau pemanja [21]. Tipe ketiga ini kerap memberikan pengawasan yang sangat longgar, memberikan kesempatan pada anaknya untuk melakukan sesuatu tanpa pengawasan yang cukup darinya, cendrung tidak menegur atau memerintakan anak. Orang tua tipe ini memberikan kasih sayang yang berlebihan, sehingga karakter anak menjadi implusif, tidak patuh manja, kurang mandiri, mau menang sendiri, kurang percaya diri dan kurang matang secara sosial. Keempat pola asuh tipe penelantar (orang jawa bilang diumbar). Orang tua memberikan waktu dan biaya sangat minim pada anak-anaknya lebih memil sibuk bekerja. Karakter yang terbentuk biasanya anak-anak menjadi moody, implusif, agresif, kurang bertanggung jawab, tidak mau mengalah, harga diri yang rendah dan bermasalah dengan teman [22].

Berdasarkan hasil penelitian ditemukan bahwa pola asuh orang tua dalam membentuk kepribadian anak di masa covid 19, dilakukan dengan cara berbeda-beda, yaitu: pertama mengontrol dan mengintervensi akativitas anak, terutama dalam berbicara, melakukan sesuatu seperti penggunaan gadget (gawai), ada anak yang terlajur ketagihan yang banyak menyediakan conten-conten negatif dan menonton TV. Ada keluarga/orang tua yang selalu mengajak anaknya dalam melakukan kegiatan beribadah bersama, bermain bersama, belajar bersama. Kedua membangun komunikasi, mengembangkan kreativitas dan aspirasi anak, ketiga orang tua lebih dapat menguasai diri dalam menyesuaikan dan memahami anak-anak mereka. Orang tua belajar menguasai diri menghadapi kenakalan dan prilaku yang dianggap tidak sesuai dari anak. Berusaha menyelesaikan masalah dalam keluarga terutama yang berkaitan dengan anak dengan bijaksana. Keempat Ayah da ibu selalu lebih kompak dan bersatu dalam mengasuh anak-anak, membangun chemistry kekompakan dalam berkomunikasi serta membuat perencanaan dan kesepakatan dalam berbagai hal yang akan dilakukan terutama dalam pembagian tugas. Kelima Berusaha memberikan contoh yang kongkrit seperti tatacara bersikap, berbicara, beribadah, adab makan minum, berkomunikasi termasuk menghargai waktu. Keenam memperlakukan anak sebagai teman dalam berbagai aktivitas, mendampingi, menemani, bermain bersama, dan memberikan tugas dan tanggung jawab (pekerjaan rumah). Ketujuh Lebih berusaha memahami karakter, potensi dan kepribadian anak, (cerdas, sensitif, reaktif, hiperaktif, pemalu, pendiam, pemarah, dan lain sebagainya). Kedelapan membangun pola Interaksi, hal ini dikarenakan seringnya keluarga bertemu. Kesembilan orang tua berusaha melek teknologi, hal ini dikarenakan banyak hal yang dilakukan membutuhkan teknologi secara online. Kesepuluh membantu anak menyelesaikan tugas-tugas terutama dari sekolah (bagi anak yang sudah sekolah PAUD).

Berdasarkan temuan peneltian berikut dijelaskan masing-masing pola asuh yang diterapkan oleh orang tua di Kelurahan Baruga dimasa pandemi covid 19 dalam membentuk karakteristik dan kepribadian anak, yaitu: Pola asuh demokratis (autoritatif) yakni; orang tua banyak memperhatikan dan terlibat dan bekerjasama dengan anak dalam melakukan aktivitas, baik terhadap anak kegiatan belajar seperti membantu mengerjakan pekerjaan dan tugas yang diberikan oleh gurunya, membantu 
mengirim hasil pekerjaan dari tugas-tugas sekolah maupun aktivitas lain yang dilakukan anak dalam keseharian selama tinggal dirumah. Hal ini ditandai dengan ikut terlibat dalam kegiatan, membagi waktu belajar dan bermain dengan anak tanpa harus memaksa pada anak, tidak terlalu membiarkan atau membatasi anak menonton TV, memegang gadget (HP) hanya pada saat waktu belajar, menegur dan menanyakan sebab-sebabnya bila anak tidak belajar, tidak memaksa anak untuk belajar sesuai kehendaknya, selalu memperhatikan kebutuhan sekolah anak, menemani anak saat belajar walaupun tidak terlalu sering, memberi uang saku pada anak secukupnya saja, selalu memperhatikan sarana prasarana belajar anak, sering meluangkan waktu untuk berdiskusi dengan anak, melatih anak untuk bertanggung jawab, meminta anak untuk membantu pekerjaan dirumah yang sesuai dengan kemmampuan dan apabila anak melakukan kesalahan, hukuman yang diberikan bersifat mendidik.

Pola asuh otoriter (authoritarian) yakni orangtua melakukan pengasuhan dan penjagaan yang ketat ditandai dengan ketatnya orangtua dalam membagi waktu aktivitas/kegiatan dan bermain anak, tidak membolehkan anak menonton televisi pada saat anak menginginkan, memarahi anak dan mencaci maki bahkan memukul apabila anak tidak melakukan apa yang diperintahkan, memaksa anak untuk melakukan sesuatu sesuai kehendaknya, tidak terlalu memperhatikan kebutuhan anak, selalu mengawasi anak, jarang memberi uang jajan, kalaupun diberi sering disertai nasehat-nasehat bernada mengancam, jarang meluangkan waktu untuk berdiskusi, beraktivitas dengan anak, tidak melatih dan memberikan tanggung jawab pada anak, kalaupun diberi tanggung jawab dan bila anak melakukan kesalahan dimarahi atau dipukuli, dihukum tanpa diberi kesempatan untuk membela diri.

Pola asuh permisif (permissive) yang dilakukan oleh orangtua ditandai dengan tidak membiasakan anak membagi waktu beraktivitas, belajar dan bermain sendirian, selalu membiarkan anak memutar TV pada saat/waktu belajar sesuka keinginannya, tidak menanyakan atau menegur bila kesalahan anak apa pun yang dilakuakn, tidak memperhatikan kebutuhan utama anak, tidak pernah menemani saat anak belajar, tidak menasehati anak, membiarkan anak melakukan apa saja sesuai keinginannya, memberikan apa saja yang diinginkan teruma yang berkaitan dengan materi, tidak pernah meluangkan waktu untuk berdiskusi dan mendampingi anak, tidak melatih anak untuk bertanggungjawab, dan membiarkan saja anaknya sekalipun ia melakukan kesalahan, hal terutama dilakukan oleh orang tua yang sibuk dan bekerja keras penuh waktu.

Pola asuh tidak terlibat (neglectful/ uninvolved) yakni orang tua tidak yang tidak mau terlibat dalam perkembangan anak, tidak memiliki nilai yang tinggi pada dimensi kehangatan dan kontrol. Pola asuh ini dilakukan orang tua yang lalai dan perhatian rendah pada anaknya baik dalam hal pemenuhan kebutuhan maupun pengembangan kedisiplinan, pekerjaan, belajar, beradab dan berakhlak tidak menjadi kepedulian. Hubungan antara orang tua dan anak kurang hangat, orang tua tidak banyak terlibat atau cenderung pasif terhadap kehidupan anak, dan orang tua cenderung menjaga jarak. Namun, orang tua tetap memperhatikan dan menyediakan kebutuhan dasar anak seperti makanan, pendidikan, rumah, dan lain-lain.

Hasil analisis menunjukan bahwa setiap orang tua memiliki pola asuh tersendiri dalam membentuk kepribadian anak dimasa pandemi covid 19, hal ini sangat dipengaruh oleh latar belakang pendidikan, mata pencaharian hidup, keadaan social, ekonomi, adat istiadat, dan sebagainya. Dengan kata lain, pola asuh orang tua petani, pekerja buruh tidak sama dengan pedagang, demikian pula pola asuh orang tua berpendidikan rendah berbeda dengan pola asuh orang tua yang berpendidikan tinggi. 
Ada yang menerapkan dengan pola yang keras/kejam, kasar, dan tidak berperasaan. Namun, ada pula yang memakai pola lemah lembut, dan kasih sayang. Selain itu ada juga yang memakai sistem militer, yang apabila anaknya bersalah akan langsung diberi hukuman dan tindakan tegas. Bermacam-macam pola asuh yang diterapkan orang tua ini sangat berdampak pada karakter, kepribadian, psikologis anak.

Koentjaraningrat mengatakan bahwa bentuk-bentuk pola asuh orang tua sangat erat hubungannya dengan kepribadian anak setelah ia menjadi dewasa. Hal ini dikarenakan ciri-ciri dan unsur-unsur watak seorang individu dewasa sebenarnya sudah diletakkan benih-benihnya ke dalam jiwa seorang individu sejak sangat awal, yaitu pada masa ia masih kanak-kanak. Watak juga ditentukan oleh cara-cara ia waktu kecil diajar makan, diajar kebersihan, disiplin, diajar main dan bergaul dengan anak lain dan sebagainya [23]. Dengan demikian, dapat dipahami bahwa pola asuh yang diterapkan oleh orang tua sangat dominan dalam membentuk kepribadian anak sejak dari kecil sampai anak menjadi dewasa. Selanjutnya Clemes Haris mengatakan bahwa Perilakuperilaku anak akan menjadikan penyempurna mata rantai interaksi anggota keluarga dan pada saat yang sama interaksi ini akan membentuk kepribadiannya secara bertahap dan memberikan arah serta menguatkan perilaku anak pada kondisi-kondisi yang sama dalam kehidupan[24] sehingga G.D Wilson menyimpulkan secara umum kepribadian ekstravert menunjukkan suka bergaul, suka keluar, sociable, suka mencoba, menonjol, suka berpetualangan. Sedangkan introvert lebih hati-hati, terkendali, pendiam, menarik diri atau suka menyendiri [25].

Setiap anak memiliki perkembangan yang berbeda olehnya orang tua dalam pengasuhan harus memahami dan mengenali karakter dan sifat anak, ada anak yang mudah belajar, aktif, pendiam, susah diatur, suka meniru, aktif bergerak dan mudah beradaptasi. Melansir akun resmi instagram Sahabat Keluarga Kemendikbud menekankan bahwa ciri-ciri anak usia dini adalah; unik, senang meniru, senang bermain, spontan, aktif bergerak, mengutamakan keinginan diri sendiri, rasa ingin tahu tinggi, senang berimajinasi, konsentrasi pendek dan mudah frustasi [26]. Oleh karenanya perlu dipahami bahwa sebagai makhluk sosial, manusia tidak akan lepas dari lingkungan kehidupan sosial yang penuh dengan nilai, peraturan dan norma. Nilai, peraturan dan norma tersebut sangat diperlukan manusia untuk membedakan mana yang baik dan yang buruk, mana yang benar dan mana yang salah, mana yang jika dilakukan berdosa mana yang tidak tidak berdosa. Pemahaman yang baik terhadap nilai dan norma akan membawa pola asuh yang baik pula terhadap prilakuitas anak sehingga mereka dapat hidup harmonis di lingkungannya. Berikan dukungan bagi anak anda dengan membantu mereka untuk tetap aman pada saat belajar online/dalam jaringan (daring). "Perlakuan orang tua terhadap anak memberikan kontribusi yang amat besar terhadap kompetensi sosial, emosi, dan kemampuan kecerdasan atau intelektual anak," jelas Rose dalam acara puncak peringatan Hari Anak Nasional yang digelar di Gedung Siwabessy Kemenkes, [27]. Oleh karena itu, pola asuh orang tua sangat berperan bagi anak usia dini, dimana orang tua mendidik anaknya dengan sangat baik mulai dari lingkungan internal keluarga. Konsep dan pola asuh orang tua untuk anaknya harus mempunyai jiwa yang bisa merawat, membantu, mendidik, membimbing dan melatih anak agar menjadi anak yang tumbuh kembang secara kreatif, baik dan patuh, bisa menjadikan anak merasa mempunyai tanggung jawab serta percaya diri dan dapat menerima pahit manisnya kehidupan ketika dewasa kelak. Untuk itu jadilah orang tua yang berpikiran positif, 
kreatif dan aktif dalam tumbuh kembang anak pada usia dini. Peran orang tua sebagai pengawas di keluarga atau pengawas anggota keluarganya dari penyebaran covid-19 dengan cara memberikan edukasi contoh kepada anggota keluarga terutama kepada anak-anak [28]. Pengunaan masker baik masker kain maupun masker bedah, penerapan perilaku hidup bersih dan sehat serta pelibatan orangtua dalam menskrining peserta didik sangat diharapkan sehingga dapat mencegah peserta didik dari penularan virus covid-19 di lingkungan sekolah[29].

\section{KESIMPULAN}

Model pola asuh orang tua memiliki pengaruh sangat besar terhadap perkembangan kepribadian anak. Orang tua dengan model pola asuh otoriter akan cenderung menghasilkan anak dengan ciri kurang matang, kurang kreatif dan inisiatif, tidak tegas dalam menentukan baik buruk, benar salah, suka menyendiri, kurang supel dalam pergaulan, ragu-ragu dalam bertindak atau mengambil keputusan karena takut dimarahi. Anak yang diasuh dengan pola asuh demokrasi akan mengembangkan kepribadian rasa percaya diri, dapat bekerja sama, bersosialisasi, empati, menghargai orang lain, terbuka, dan bertanggung jawab. Sebaliknya anak yang diasuh dengan pola asuh permisif akan mengembangkan kepribadiannya lebih egois, cuek, sering ingin mau menang sendiri, dan berharap semua keinginannya akan terpenuhi. Mereka kurang mampu bersosialisasi dan menyesuaikan diri, selalu merasa gelisah atau berperasaan tidak menentu, menggunakan banyak mekanisme pembelaan diri, demikian pula dengan pola asuh tidak terlibat akan membentuk anak menjadi pribadi yang selalu merasa tidak nyaman, tidak perduli, tempramen, tidak menghargai orang lain dan selalu melakukan sesuatu dengan kehendaknya. Pola asuh berkaitan dengan karakteristik setiap individu dan inilah yang sekaligus membedakan dalam berbagai bidang seperti bidang akademik, sosial, kepribadian atau keterampilan lain, yang menjadikan anak memiliki sesuatu yang bernilai tinggi dan akan mengembangkan kepribadiannya. Bimbingan, pengasuhan dan pemberian kasih sayang secara langsung maupun tidak langsung akan membawa dampak yang cukup besar terhadap perkembangan karakter dan kepribadian anak. Kondisi lingkungan keluarga dengan model pola asuh tertentu jelas akan mempola asuhi cara bertutur kata, cara sikap, dalam keseharian anak termasuk perkembangan psikososial dan emosionalnya.

\section{PENGHARGAAN}

Terima kasih penulis ucapkan kepada orang tua anak yang menjadi informan penelitian di Kelurahan Baruga kota Kendari serta semua pihak yang terlibat dan membantu terlaksananya penelitian ini. Tidak lupa diucapan terima kasih kepada editor dan reviewer Jurnal Murhum yang sudah memberikan kesempatan sehingga jurnal bisa untuk dipublish/diterbitkan.

\section{REFERENSI}

[1] L. Anhusadar, "Persepsi Mahasiswa PIAUD terhadap Kuliah Online di Masa 
Pandemi Covid 19," KINDERGARTEN J. Islam. Early Child. Educ., vol. 3, no. 1, p. 44, Apr. 2020.

[2] worldometers info, "worldometers info coronavirus," https://www.worldometers.info/coronavirus/, 2020. [Online]. Available: https://www.worldometers.info/coronavirus/.

[3] Satgas, "Satuan Tugas Covid-19," covid19.go.id, 2020. [Online]. Available: https://covid19.go.id/.

[4] I. Rakhmawati, "Peran Keluarga dalam Pengasuhan Anak," J. Bimbing. Konseling Islam, vol. 6, no. 1, pp. 1-18, 2015.

[5] Kemenkes RI, "Kesiapsiagaan Menghadapi Infeksi Novel Coronavirus," kemenkes.go.id, 2020. [Online]. Available: https://www.kemkes.go.id/article/view/20012900002/Kesiapsiagaanmenghadapi-Infeksi-Novel-Coronavirus.html.

[6] Kompas, "6 Tips Pola Asuh Anak ala Victoria Beckham," Kompas.com, 2019. [Online]. Available: https://lifestyle.kompas.com/read/2019/07/23/073809220/6-tips-pola-asuhanak-ala-victoria-beckham?page $=2$.

[7] Sjarkawi, Pembentukan Kepribadian Anak Peran Moral, Intelektual, Emosional dan Sosial sebagai Wujud Integrasi Membangun Jati Diri. Jakarta: Bumi Aksara, 2011.

[8] U. Hasyim, Anak Soleh (Cara Mendidik Anak Dalam Islam). Surabaya: PT. Bina Ilmu, 2003.

[9] Departemen Agama RI, Al-Qur'an Terjemahan. Bandung: CV Darussunah, 2015.

[10] Y. Badudu, Kamus ungkapan bahasa Indonesia. Penerbit Buku Kompas, 2008.

[11] Baumrind (Silalahi), Keluarga Indonesia Aspek dan Dinamika Zaman. Jakarta: Rajawali Press, 2010.

[12] Abu Ahmadi, Pendidikan Ilmu. Jakarta: PT. Rineke Cipta, 2001.

[13] J. Aris Try Andreas Putra, Sufiani, "Transformasi Nilai Pendidikan Islam Anak di PAUD Sultan Qaimuddin Kendari Pada Masa Pandemi Covid 19," Murhum J. Pendidik. Anak Usia Dini, vol. 1, no. 1, 2020.

[14] R. Tanjung, "Peran Orangtua dalam Pendidikan Anak Usia Dini di Masa Pandemi Covid-19," Murhum J. Pendidik. Anak Usia Dini, vol. 1, no. 2, pp. 64-73, 2020.

[15] UNICEF, "Kiat Pengasuhan di Tengah Wabah Virus Corona (COVID-19)," unicef.org, $2020 . \quad$ [Online]. Available: https://www.unicef.org/indonesia/id/coronavirus/kiat-pengasuhan-COVID19\#top.

[16] A. C. Alwasilah, Pokoknya kualitatif: Dasar-dasar merancang dan melakukan penelitian kualitatif. Pustaka Jaya, 2002.

[17] R. K. Yin, "Case study research: Design and methods, applied social research," Methods Ser., vol. 5, 1994.

[18] H. Heriyanto, "Thematic Analysis sebagai Metode Menganalisa Data untuk Penelitian Kualitatif," Anuva, vol. 2, no. 3, p. 317, Nov. 2018.

[19] H. Machmud, "Pengaruh pola asuh terhadap keterampilan sosial anak (Penelitian expost facto pada paud rintisan di Kendari)," Al-TA'DIB J. Kaji. Ilmu Kependidikan, pp. 127-145, 2019.

[20] M. B. Lail, "Pengaruh Pola Asuh Dan Interaksi Sosial Terhadap Akhlak Siswa di Sekolah Menengah Pertama Islam Terpadu Nurul Azizi Kota Medan," EDU-RILIGIA J. Ilmu Pendidik. Islam dan Keagamaan, vol. 1, no. 4, 2017.

[21] S. Wahyuningsih, "Pola asuh anak keluarga tenaga kerja wanita (TKW) di Desa Arjowilangun Kecamatan Kalipare Kabupaten Malang," Kaji. Moral dan 
Kewarganegaraan, vol. 5, no. 03, 2017.

[22] K. S. Widiantari and Y. K. Herdiyanto, "Perbedaan intensitas komunikasi melalui jejaring sosial antara tipe kepribadian ekstrovert dan introvert pada remaja," J. Psikol. Udayana, vol. 1, no. 1, pp. 106-115, 2013.

[23] M. M. Al-Istanbuli, "Mendidik Anak Nakal," Bandung: Pustaka, 2002.

[24] I. M. P. Aryana, "Kontribusi Orang Tua Dalam Menumbuhkan Budaya Literasi Anak," Pros. Nas., pp. 141-153, 2019.

[25] I. Z. Ratnaningsih, "Manajemen emosi sesuai tuntutan kerja (emotional labor) ditinjau dari tipe kepribadian pada wiraniaga," J. Psikol. Undip, 2017.

[26] Kemendikbud "Sahabat Keluarga Kemendikbud," https://sahabatkeluarga.kemdikbud.go.id/, 2020. [Online]. Available: https://sahabatkeluarga.kemdikbud.go.id/.

[27] ISTA, "Ibu Rumah Tangga dan Organisasi Perempuan Ujung Tombak Tekan Penularan Dalam Klaster Keluarga," covid19.go.id, 2020. [Online]. Available: https://covid19.go.id/p/berita/ibu-rumah-tangga-dan-organisasi-perempuanujung-tombak-tekan-penularan-dalam-klaster-keluarga.

[28] E. Kurniati, D. K. Nur Alfaeni, and F. Andriani, "Analisis Peran Orang Tua dalam Mendampingi Anak di Masa Pandemi Covid-19," J. Obs. J. Pendidik. Anak Usia Dini, vol. 5, no. 1, p. 241, May 2020.

[29] M. Shaleh and L. Anhusadar, "Kesiapan Lembaga PAUD dalam Pembelajaran Tatap Muka pada New Normal," J. Obs. J. Pendidik. Anak Usia Dini, vol. 5, no. 2, pp. 21582167, Mar. 2021. 